\title{
Production Analysis of Banana Supply Chain Management in Thailand
}

\author{
Adisak Suvittawat ${ }^{1, *}$ \\ ${ }^{1}$ International College, Burapha University, Chonburi 20131, Thailand \\ *Correspondence: International College, Burapha University, 169 Long Hard Bangsean Road, Saen Sook, Chonburi \\ 20131, Thailand. Tel: 66-3810-2571. E-mail: adisaku@buu.ac.th
}

$\begin{array}{ll}\text { Received: October 14, } 2014 & \text { Accepted: October 26, } 2014 \quad \text { Online Published: November 25, } 2014 \\ \text { doi:10.5430/mos.v2n1p66 } & \text { URL: http://dx.doi.org/10.5430/mos.v2n1p66 }\end{array}$

\begin{abstract}
The objective of this research is to identify the main concerning factors of Thai banana farmers' production.

This study was used primary data from interviews with banana farmers. Secondary data were used from literature review for confirmation.

This study found that the problems begin at the seedling stage, when low survival rates affect the numbers of bananas per area, the growth rate of seedlings, the appropriate seedling age, plant material durability and higher production costs.

The main problems at the growth stage that must be managed by farmers include soil fertility, suitable fertilizer methods and application rates, weevil infestations, and drought conditions.

Banana yields and quality have an impact on farmers' incomes since higher yields provide higher incomes. Good quality crops offer farmers absolute benefits, since farmers can then sell bananas at a high price and their bananas won't be rejected.

Production is an important part of banana supply chain management. Methods or technologies must be identified and applied to create value for farmers. This also benefits consumers since they want high quality bananas and chemical-free bananas. Thailand's banana industry must consider various aspects of production as importers or importing countries are currently asking for high quality bananas that are also free of any chemical residue.
\end{abstract}

Keywords: banana; production; analysis; supply chain management; Thailand

\section{Introduction}

Bananas are one of Thailand's major fruit crops; they have been increasingly important not only for domestic consumption but also for overseas exports. There are many challenges for Thai banana production that are related to uncontrollable environmental factors and farmer capabilities.

Banana production stakeholders can only reap benefits from supply chain management when they clearly understand what this means. Some of the added benefits are profit increasing and operation or production improvement. Since banana demand is always changing, production must adapt rapidly to changes to maintain a consistent supply in order to compete with other banana exporters.

Usually, supply chain management focuses only on customer needs or the customer's perspective. Studies from the production perspective, especially in supply chain management, are very rare in Thailand's banana industry. It is an important area to study as it will provide fundamental and detailed knowledge for supply plan creation.

\section{Literature Review}

The most influential factors on net corn yields and production costs are the following: the environment and soil fertility; corn variety; fertilizer application rates and methods. Appropriate fertilizer methods and application rates have significantly improved yields (Bakhtiari et al., 2014). 
Since vegetables and fruit can rot, they have a limited shelf life. It is important therefore to understand how best to transport them so they reach buyers in time. Studying how buyers make banana purchasing decisions includes knowing how buyers assess the quality of the fruit and how ripe bananas should be when they arrive at the store (Nairn, 1999).

The ripening process for bananas is very sensitive to temperature and weight is very important to determining banana quality. Banana quality is most influenced by the loss of attributes such as peel color, the softness of the pulp, and sweetness. However, only one attribute could not be used for express loss of banana quality, it needs more attribute to express banana quality loss (Nunes et al., 2013).

The 'banana weevil', or the pseuostem weevil ( Odoiporus longicollis), is one of the worst banana crop pests, since it can destroy the roots and stem, which affect the banana yield. The banana weevil lays eggs in the chamber of the outside sheath and will take hold later on. When weevils take over the banana stem, they weaken and then destroy the plant (Irulandi et al., 2012).

Drought is a consequence of too little rainfall. Drought conditions can cause strong winds and low humidity, which can damage plants during planting. This is when the plants are sensitive to low soil moisture and can lower yields (Nikolova, 2013).

\section{Methodology}

This exploratory research aims to identify new factors that affect banana supply chain management, particularly from the production perspective. The study explored problems that concerned farmers.

Quantitative methods were applied, using questionnaires as qualitative contextual tools. Secondary data came from a literature review and was used to confirm research findings.

The research process began with a literature review. A measurement parameter for the key factors was created, which required consultations with supervisors and experts, before conducting the initial surveys with the farmers. Measurements were applied to the results of the final version of the surveys. The survey results were analyzed using a percentage model. The conclusions were drawn from the study's findings.

The final version of the questionnaires was distributed among 153 banana farmers. The questionnaires were divided into four parts, reflecting the research parameter measurements.

The initial questionnaires focused on seedling problems such as low survival rates, growth rates, poor health, suitable seedling age preparation, planting materials that are not durable and high production costs.

The second version of the questionnaires focused on soil nutrients, suitable fertilizer rates and application times, banana weevil infestation, drought conditions, labor shortages and high costs.

The third round of questionnaires focused on banana crops that had lower yields. Low yields were caused by small and unattractive banana hands (clusters or bunches of 10-20 banana fingers), undeveloped banana fingers, too few banana hands per stem and difficulty in managing quality control.

The final questionnaires focused on the consistency of quality control at farms, the diversification of banana products, quality variations in each production batch, the length of time before a return on investment and supply inconsistencies.

\section{Results}

Table 1. Problems at Seedling Stage

\begin{tabular}{ll}
\hline Variable & Percentage \\
\hline 1 Seedlings have low survival rate & 80.2 \\
2 Slow growth rate and poor seedling health & 76.5 \\
3 Suitable seedling age preparation & 75.3 \\
4 Planting materials are not durable & 75.1 \\
5 Production cost is high & 74.9 \\
\hline
\end{tabular}

*Number of respondents $=153$

Table 1 shows the problems farmers have at the banana seedling stage. Problems with seedlings that had a lower survival rate were the most important, at $80.2 \%$. Seedlings that did not grow fast enough and were not healthy were 
rated at $76.5 \%$. Problems with suitable seedling age preparation was rated at $75.3 \%$, and for planting materials that were not durable enough, was at $75.1 \%$ Finally, farmers rated high production cost problems at $74.9 \%$.

The results indicate that banana farmers have problems when they prepare seedlings for planting. Low survival rates and low growth rates lead to low banana yields. In America, chestnut production research found that the early survival of chestnut seedlings depended on many factors, such as disease or primary root rot. Seedlings that did not show symptoms of disease had high survival rates and also had a fast growth rate (Clark et al., 2014).

Suitable seedling age preparation improves plant survival rates and yields. Appropriate seedling age preparation can strengthen the plant, particularly under stressful environmental conditions. In rice production, the most important success factors for higher yields are first, vigorous seedlings and then, transplanting seedlings at an appropriate age. Rice plants with a low plant population that had sufficient nitrogen had higher yields. In contrast, rice with a high plant population that did not have enough nitrogen had poor yields. In rice production the most important factors are the growth rate and the health of the seedling (Sarwar et al., 2011).

Having durable planting materials was very important as this was not only cost-saving but it also protected banana seedlings longer, as materials were reused when the new seedling batch was prepared and they stayed longer in the field, which protected banana seedlings from an uncertain environment. In Africa, particularly in commercial banana production, there are problems with limitations of tissue culture technology in banana seedling production. A reliable and durable system is really needed for banana tissue culture improvement and sustainability. A major constraint for banana farmers is the lack of access to credit to purchase the planting materials required for tissue culture technology. Durable planting materials would help banana farmers reduce their costs (Murugi Kahangi, 2010).

Since the production environment is always changing and banana production costs are difficult to predict, production cost management is a major part of a farmer's decision-making in terms of farm input investments. The breeding cycle, world inventories, consumption changes and weather are all uncertainties that have an impact on farm income, making it difficult to create a buffer stock. Short-term production decisions are mainly based on the correlation between operation costs and estimated products or farm gate prices while production costs have been calculated as a financial success factor. Producers are aware of their production costs (McBride, 2003).

Table 2. Problems during Banana Growth in Farmer Fields

\begin{tabular}{ll}
\hline Variable & Percentage \\
\hline 1 Soil lacks nutrition & 82.1 \\
2 Suitable fertilizer rate and application time & 80.5 \\
3 Banana weevil infestation & 80.2 \\
4 Drought conditions & 79.8 \\
5 Labor shortage and high cost & 77.3 \\
\hline
\end{tabular}

*Number of respondents $=153$

Table 2 shows the problems that occur as bananas grow in farmer fields. The most serious problem was poor soil nutrition, at $82.1 \%$. Suitable fertilizer rates and application times ranked second, at $80.5 \%$. Banana weevil infestations was third, at $80.2 \%$. Drought conditions ranked $79.8 \%$ as a problem and the final challenges were labor shortages and high costs, at $77.3 \%$.

Infertile soil or soil with too little nutrition lowered banana yields since bananas could not get enough nutrition. Seed germination is significantly dependent on specific environmental conditions which affect seedling establishment. Individual growth rates of seedlings are slow and limited when soil nutrients and water are inadequate. Plant growth rates finally depend on the plant's maturity-(Mondragon et al., 2015).

Banana nutrition depends on the plant's growing stages, which require different amounts of fertilizer. The reproductive stage requires more potassium than nitrogen. The appropriate fertilizer rates that give nutrients at different ratios improve yields. Application time is crucial as bananas need different nutrients at different stages. Net corn yields for example, significantly increased when fertilizer rates were increased from 30 to $90 \mathrm{~kg} / \mathrm{ha}$, even though corn height and the amount of corn cobs were not significantly different. The application rate of fertilizer had a direct influence on net corn yield (Bakhtiari et al., 2014).

Crop pests destroy plants and reduce yields. The main banana pest is known as the banana weevil. It is hard for farmers to control them since their survival rate is high and they have already lived in previous banana trees. They destroy the banana rhizome and pseudostem base. High weevil densities in local commercial banana fields might 
lead to infestation in new banana plants by adult weevils that lived in the residue from previously harvested banana trees (Graaf et al., 2008).

Table 3. Problems of Banana Yield and Quality

\begin{tabular}{ll}
\hline Variable & \\
\hline 1 Lower banana yields & 89.3 \\
2 Small and unattractive banana hands & 86.4 \\
3 Undeveloped banana fingers & 85.2 \\
4 The ratio of banana hand per stem is low & 80.1 \\
5 Quality control is very difficult & 79.4 \\
\hline
\end{tabular}

*Number of respondents $=153$

Table 3 shows the problems of banana yields and quality. The most significant problem was low yields, at $89.3 \%$. Small and unattractive banana hands ranked second, at $86.4 \%$. The problem of undeveloped banana fingers was rated at $85.2 \%$., while problems with a low ratio of banana hands per stem ranked fourth, at $80.1 \%$. Difficulties with quality control came in last, at $79.4 \%$.

Yield is very important for farmers since it reflects their incomes. Most farmers needed high yields. They had different strategies to improve yields, such as choosing a good quality banana variety, investing in good quality fertilizers, and adopting good agricultural practices. The main yield constraints were identified as poor soil quality, harvesting at the wrong time, and poor weed management. The highest yield fields did not have these problems because those farmers had good crop management knowledge (Sopheap et al., 2012).

The 'banana hand' refers to the yield components. Big banana hands produce more bananas than small hands, so they are more lucrative. Hand removal from the field significantly increases yield as it provides good pest management, also reduces fruit susceptibility to threats, and increases fruit size (Lassois et al., 2010).

Bananas with undeveloped fingers had lower yields. Usually fingers will drop as bananas ripen and this comes from changes in the cell walls of modified genes. Finding ways to protect finger-dropping and peel-softening will improve banana yield and quality (Imsabai et al., 2006).

Banana quality consists mainly of color and texture, and is sensitive to environmental change. Quality does not refer only to the fruit, but also the selling price. Excellent quality gets a higher price than lower quality. Quality control is very crucial for banana exports since importers always strictly control quality. Color measurements showed lightness and yellowness when bananas had a preservative coating. It is strongly recommended to coat bananas with materials such as hemicellulose to prevent them from turning brown (Yilmaz \& Cekmecelioglu, 2013).

Table 4. Production Problems of Banana Industry

\begin{tabular}{ll}
\hline Variable & \\
\hline The consistency of quality control on farms & 85.6 \\
2 The diversification of banana products & 82.1 \\
The variation of quality in each production batch & 80.3 \\
4 The return of investment is long & 79.5 \\
5 Inconsistent banana supply & 78.6 \\
\hline
\end{tabular}

*Number of respondents $=153$

Table 4 shows the banana industry's production problems. The biggest problem was the consistency of quality control on farms, at $85.6 \%$. The diversification of banana products was the next most serious problem, at $82.1 \%$. The third biggest problem was quality variations in each production batch, which rated $80.3 \%$. Then there were concerns that the return of investment took too long, and this problem was rated at $79.5 \%$. The final problem mentioned was inconsistencies in banana supply, at $78.6 \%$.

Farm quality control was absolutely important, particularly for chemical fertilizer and pesticide control, as chemical residues affect consumer health. Some importing countries reject bananas if the chemical residue is higher than standard levels. A survey of chlordecone chemical residue in banana plantations found traces of chlordecone in the soil, river and food products.

Product diversification gives the opportunity to increase trade. Currently, Central American banana exports might be lower when compared with other regions. Some countries have not stabilized their export value and earnings since they have only one main export product, but some countries, such as Honduras, enjoy good banana revenues due to product diversification (Stanley \& Bunnag, 2001). 
Since product quality varies from one hand to another, quality control is very difficult. Mediterranean countries created production strategies for edible crop quality control by using the greenhouse method. The greenhouse method is easier to control both for environmental and pest control factors. This provides consistency, and better crop quality, and this also helps to encourage customer loyalty (Castilla, 2002).

Return on investment has become a major issue for farmers as they rely so much on loans. A fast return on investment crops attracts farmers. For example, researchers found that when crab yields were high then the return on investment was high. Even if the return on investment is high, natural resources are limited so there is a need for genetic improvement programs that focus on larger harvests and high yields (He et al,. 2014).

Environmental changes always have an impact on agricultural products, especially during drought conditions, which lead to crop supply inconsistencies. The consequence of an inconsistent supply could create additional costs for distributors as they cannot meet market demand. Retail prices dramatically increase because of supply disruptions. In Central American countries, storms during the growing period lowered banana yields and created a supply shortage (Smith 2008).

\section{Conclusion}

Many factors that affect banana supply chain management have been identified in this research.

Problems begin at the seedling stage, when low survival rates affect the numbers of bananas per area, the growth rate of seedlings, the appropriate seedling age, plant material durability and higher production costs.

The main problems at the growth stage that must be managed by farmers include soil fertility, suitable fertilizer methods and application rates, weevil infestations, and drought conditions.

Banana yields and quality have an impact on farmers' incomes since higher yields provide higher incomes. Good quality crops offer farmers absolute benefits, since farmers can then sell bananas at a high price and their bananas won't be rejected.

Production is an important part of banana supply chain management. Methods or technologies must be identified and applied to create value for farmers. This also benefits consumers since they want high quality bananas and chemical-free bananas. Thailand's banana industry must consider various aspects of production as importers or importing countries are currently asking for high quality bananas that are also free of any chemical residue.

Good supply chain management on the production side creates a competitive advantage for farmers and exporters since when costs decrease they receive more profits. Quality also improves when there is better production planning and management, and when farmers apply good practices that improve banana quality, yields and reduce chemical residue. Good practices allow Thailand to sell to countries with strict standards, such as Japan.

\section{References}

Bakhtiari, M., Ghahraei, O., Ahmad, D., Yazdanpanah, A., \& Jafari, MA. (2014). Selection of fertilization method and fertilizer application rate on corn yield. Agricultural Engineering International: CIGR Journal, 16(2), $10-14$.

Castilla, N. (2002). Current situation and future prospects of protected crops in the Mediterranean Region. Acta Horticulturae, 582, 135-147.

Clark, SL., Schlarbaum, SE., \& Hebard, FV. (2014). The first research plantings of third- generation, third-backcross American chestnut (castanea dentate) in the southeastern United States. Acta Horticulturae, 1019, 39-44.

Graaf de, J., Govender, P., Schoemman, SA., \& Viljoen, A. (2008). Efficacy of cultural control measures against the banana weevil, Cosmopolites Sordidus (Germar), in South Africa. Journal of Applied Entomology, 132, 36-44. http://dx.doi.org/10.1111/j.1439-0418.2007.01252.x

He, J., Wu, X., Li, J., Huang, Q., Huang, Z., \& Cheng, Y. (2014). Comparison of the culture performance and profitability of wild-caught and captive pond-reared Chinese mitten crab (Eriocheir sinensis) juveniles reared in grow-out ponds: Implications for seed selection and genetic selection programs. Aquaculture, 434, 48-56. http://dx.doi.org/10.1016/j.aquaculture.2014.07.022

Imsabai, W., Ketsa, S., \& van Doorn, WG. (2006). Physiological and biochemical changes during banana ripening and finger drop. Postharvest Biology \& Technology, 39(2), 211-216. 
http://dx.doi.org/10.1016/j.postharvbio.2005.10.001

Irulandi, S., Aiyanathan, A., Eraivan, K., Bhuvaneswari, B., \& Srivara, S. (2012). Assessment of biopesticides and insecticide against pseudostem weevil Odoiporus longicollis Oliver in red banana. Journal of Biopesticides, 5 , 68-71.

Lassois, L., Bastiaanse, H., Chillet, M., Jullien, A., \& Jijakli, MH. (2010). Hand position on the bunch and source-sink ratio influence the banana fruit susceptibility to crown rot disease. Annals of Applied Biology, 156(2), 221-229. http://dx.doi.org/10.1111/j.1744-7348.2009.00381.x

McBride, WD. (2003). Production costs critical to farming decisions. Amber Waves, 1(4), 38- 45.

Mondragon, D., Valverde, T., \& Hernandez-Apolinar, M. (2015). Population ecology of epiphytic angiosperms: A review. Tropical Ecology, 56(1), 1-39.

Murugi Kahangi, E. (2010). The potential of tissue culture banana (Musa spp.) technology in Africa and anticipated limitations and constraints. Acta Horticulturae, 879, 281-288.

Nairn, G. (1999). Supply chain specialists learn from banana experts: Contract Manufacturing. The Financial Times 7 October. Retrieved from http://search.proquest.com/docview/248831466?accountid=44783

Nikolova, N. (2013). The impact of the drought on the main crops cultivated in Northeastern Bulgaria. Forum Geografic, 12(1), 16-24. http://dx.doi.org/10.5775/fg.2067-4635.2013.016.i

Nunes, CN., Yagiz, Y., \& Emond, JP. (2013). Influence of environmental conditions on the quality attributes and shelf life of 'Goldfinger' bananas. Postharvest Biology and Technology, 86, 309-320. http://dx.doi.org/10.1016/j.postharvbio.2013.07.010

Sarwa, N., Maqsood, M., Wajid, SA., \& Anwar-ul-Haq, M. (2011). Impact of nursery seeding density, nitrogen, and seedling age on yield and yield attributes of fine rice. Chilean Journal of Agricultural Research, 71(3), 343-349. http://dx.doi.org/10.4067/S0718-58392011000300001

Smith, A. (2008). Weather disrupts banana supply, causes price Increase. Tribune Content Agency Retrieved from http://search.proquest.com/docview/465460248? accountid $=44783$

Sopheap, U., Patanothai, A., \& Aye, TM. (2012). Unveiling constraints to cassava production in Cambodia: An analysis from farmers' yield variations. International Journal of Plant Production, 6(4), 409-427.

Stanley, D.L., \& Bunnag, S. (2001). A new look at the benefits of diversification: lessons from Central America. Applied Economics, 33(11), 1369-1383. http://dx.doi.org/10.1080/00036840010007498

Yilmaz, CH., \& Cekmecelioglu, D. (2013). Retention of Physical Quality of Bananas by Hemicellulose Coating. GIDA/ The Journal of FOOD, 38(6), 335-342. 